\title{
Dressler's syndrome as a complication of apical ballooning cardiomyopathy
}

\author{
Davarashvili I*1, Hochberg-Klein $\mathrm{S}^{1}$, Klein ED ${ }^{2}$ \\ ${ }^{1}$ Internal Medicine Department, Hadassah Medical Organization, Jerusalem, Israel \\ ${ }^{2}$ Cardiology Department, Hadassah Medical Organization, Jerusalem, Israel
}

Received: July 23, 2017

DOI: $10.5430 /$ crim.v4n $4 \mathrm{p} 10$
Accepted: September 4, 2017

Online Published: September 8, 2017

\begin{abstract}
We report a case of 62-year-old female patient diagnosed with apical ballooning syndrome (Takotsubo) based on typical apical ballooning with normal coronaries in the setting of chest pain and ST elevation MI. Ten days after her initial hospitalization she was diagnosed with pleuropericarditis based on chest pain, pleuropericadial effusion and inflammatory markers.
\end{abstract}

This case report shows the rare complication of takotsubo cardiomyopathy (TC) - Dressler's syndrome.

Key Words: Apical ballooning, Dressler's syndrome, ST elevation MI, Chest pain

\section{INTRODUCTION}

Takotsubo syndrome was first described in 1990, and since then had been recognized more and more frequently.

Takotsubo syndrome which is also known as "stress-induced cardiomyopathy", "broken heart syndrome" and "apical ballooning syndrome", is usually an acute and reversible heart failure that can be caused by multiple triggers and is thought to be caused by catecholaminergic myocardial stunning. ${ }^{[1,2]}$ For proper diagnosis, other causes of wall motion abnormalities such as coronary heart disease, myocarditis and other types of cardiomyopathies have to be excluded. ${ }^{[3-5]}$ Takotsubo syndrome affects primarily post-menopausal women, but can also affect younger women and men. ${ }^{[6]}$ The presenting symptoms are usually of typical chest pain, palpitations and shortness of breath. ${ }^{[7]}$ In some cases, ventricular tachyarrhythmia or cardiogenic shock may ensue. ${ }^{[8,9]}$ Cardiac enzymes are elevated in about $90 \%$ of the patients but are often disproportioned to the wall motion abnormality as seen by echocardiography..$^{[9,10]}$ ECG abnormalities are seen in about $95 \%$ of patients, and might include ST segment abnormalities, $\mathrm{Q}$ wave development, $\mathrm{T}$ wave inversion and later QT prolongation. ${ }^{[8,10]}$ On angiography the coronary arteries are usually normal without significant atheromas. ${ }^{[9,11]}$ On ventriculography an apical hypokinesis is often seen. ${ }^{[12,13]}$ Echocardiography study (the noninvasive modality of choice for the diagnosis of the syndrome) typically reveal extensive areas of dysfunctional myocardium that cannot be attributed to a single coronary artery obstruction. ${ }^{[14,15]}$

Several diagnostic criteria have been proposed in recent years, in order to identify the condition as Takotsubo syndrome. In 2015 new diagnostic criteria by the Heart Failure Association of the European Society of Cardiology (HFA) were published and are as follows:

- Transient apical dyskinesia or akinesia, detected by

\footnotetext{
*Correspondence: Davarashvili I, MD; Email: idavarashvili@yahoo.com; Address: Internal Medicine Department, Hadassah Medical Organization, Jerusalem, Israel.
} 
Echocardiography color Doppler, beyond a single coronary artery distribution.

- Nonobstructive coronary artery disease (stenosis < $50 \%$ ) at angiography.

- Absence of: myocarditis, pheochromocytoma, head trauma and intracranial hemorrhage, hypertrophic cardiomyopathy.

In diagnosing takotsubo cardiomyopathy, the almost unique association of normal coronary arteries and extensive apical akinesia may be demonstrated in the acute phase of the disease. ${ }^{[16]}$

Typically, left ventricular function fully recovers within the first 12 weeks after the initial insult. ECG abnormalities may remain for long periods and sometimes forever. No study has demonstrated any mean for successful prevention of recurrence. ${ }^{[17-19]}$

\section{Case presentation}

A 62 years old married female patient with a medical history of diabetes mellitus, hypertension, smoking and hyperlipidemia was admitted to the emergency department after she had complained of chest pain accompanied by nausea, vomiting and profuse sweating. She had no prior ischemic events, nor a history suggestive of rheumatological disease. The patient's medication at home included S.C. Liraglutide $1.2 \mathrm{mg}$ q.d., Metformin $850 \mathrm{mg}$ t.i.d., Atorvastatin $40 \mathrm{mg}$ q.d. On admission, the ECG demonstrated inverted $\mathrm{T}$ waves in inferior, anterior and lateral leads (see Figure 1). Troponin levels were 0.443 (normal range $0-0.03 \mathrm{ng} / \mathrm{ml}$ ). Maximal measured levels of CPK were normal 164 (normal range 26-192 U/L).

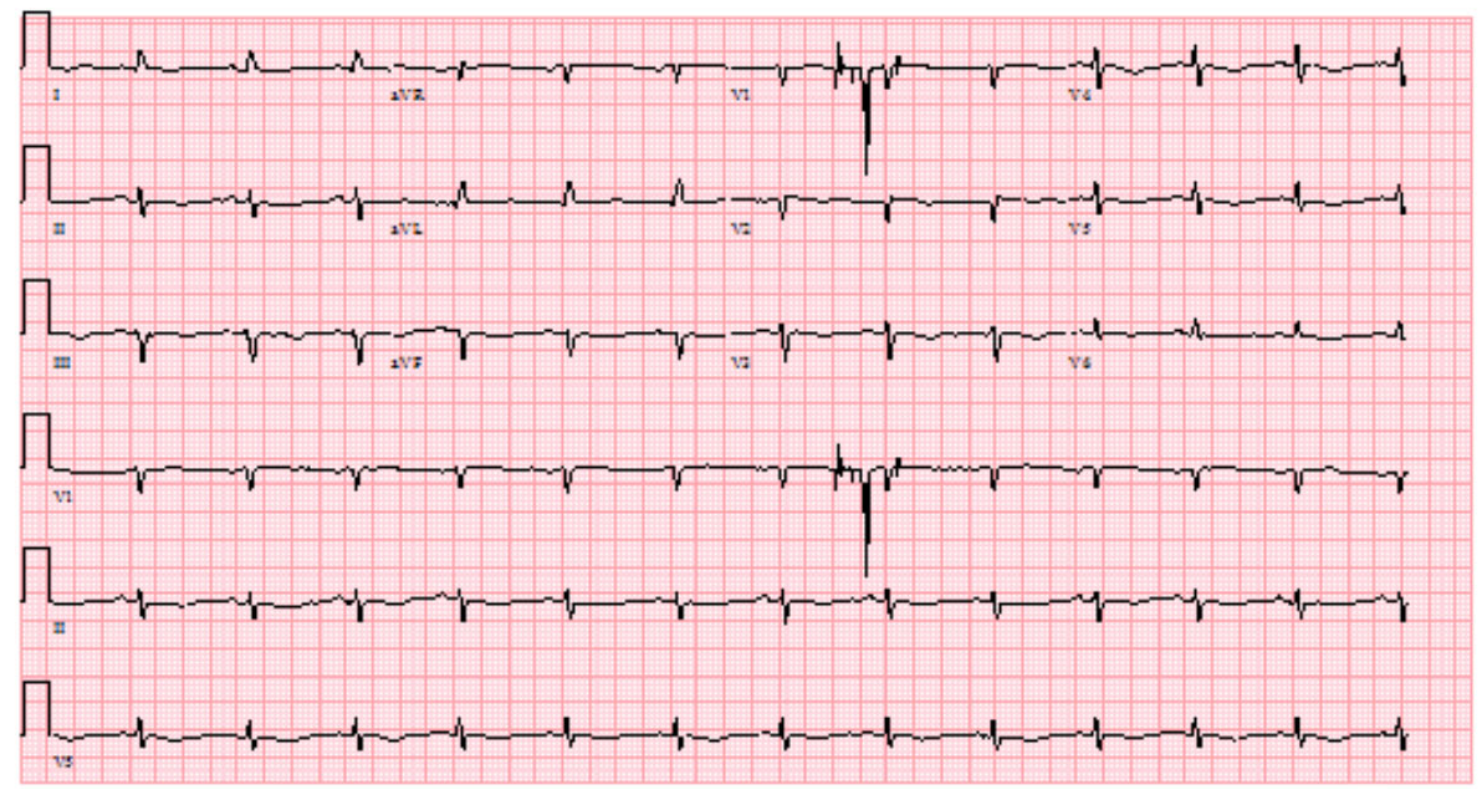

Figure 1. The ECG on admission, demonstrated inverted $\mathrm{T}$ waves in inferior, anterior and lateral leads

The patient was hospitalized with the presumed diagnosis of non ST elevation myocardial infarction.

Coronary catheterization performed a day after her arrival showed mild non obstructive coronary artery disease with typical apical ballooning (see Figure 2).

An echocardiogram showed mildly to moderately reduced left ventricular global systolic function and mildly reduced global systolic function of the right ventricle (see Figure 3).

The patient was treated with an ACE inhibitor with resolution of all her symptoms and she was discharged a few days after her admittance.

Ten days after the first hospitalization the patient returned to the emergency department with pleuritic chest pain of several hours. The patient had no prior history of viral infection. Her vital signs were within the normal range besides fever of $37.8^{\circ} \mathrm{C}$ and on cardiac auscultation no pericardial friction rub was heard.

On ECG, deeper T wave inversion were noted, as compared to previous ECG (see Figure 4). 

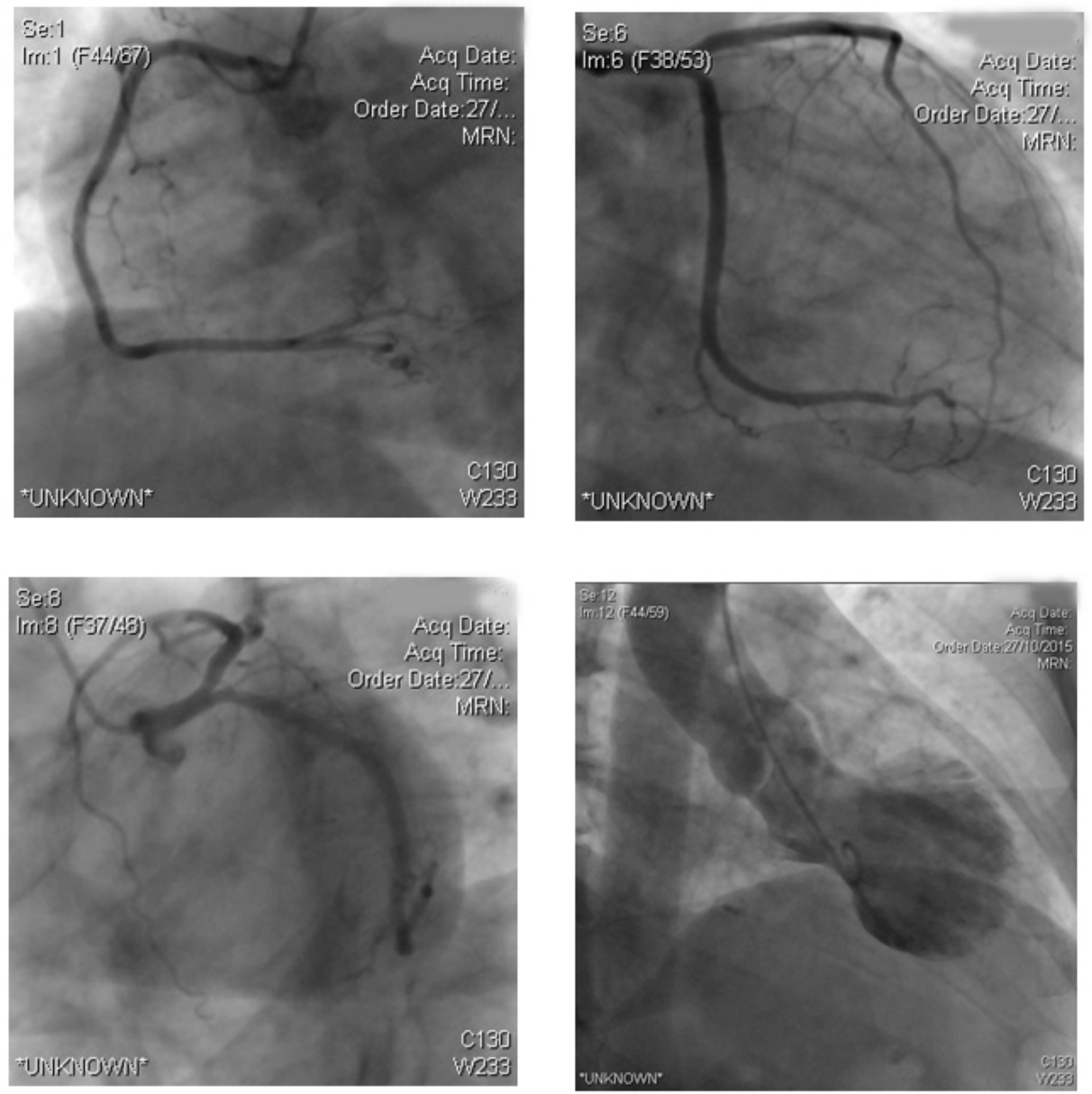

Figure 2. Coronary catheterization showed mild non obstructive coronary artery disease with typical apical ballooning

Her cardiac enzymes showed troponin of 0.009 (normal range $0-0.03 \mathrm{ng} / \mathrm{ml}$ ) and $\mathrm{CPK}$ of 48 (normal range 26-192 U/L). Her CBC showed 14,900 leukocytes (normal range 4,000-10,000 white blood cells per microliter) with $70.4 \%$ neutrophil count (normal range $50 \%-70 \%$ relative value). Her CRP was 1.8 (normal range $0-0.5 \mathrm{mg} / \mathrm{dl}$ ). Chest $\mathrm{X}$-ray revealed a small bilateral pleural effusion (see Figure $5)$.

An echocardiography examination was performed which demonstrated an improved left sided global systolic function and mild amount of pericardial fluid which did not exist on the previous exam, without any signs of a hemodynamic compromise (see Figure 6).

She was then hospitalized with the presumed diagnosis of Dressler's syndrome and we began treatment with Ibuprofen and Colchicine. Under that treatment a gradual improvement in her pain was noted, until a complete resolution. Leukocytosis and CRP, which reached a peak of 15,600 and 8.07, declined during her hospital stay to 11,500 and 2.65 (WBC/mcl and $\mathrm{mg} / \mathrm{dl}$ respectively).

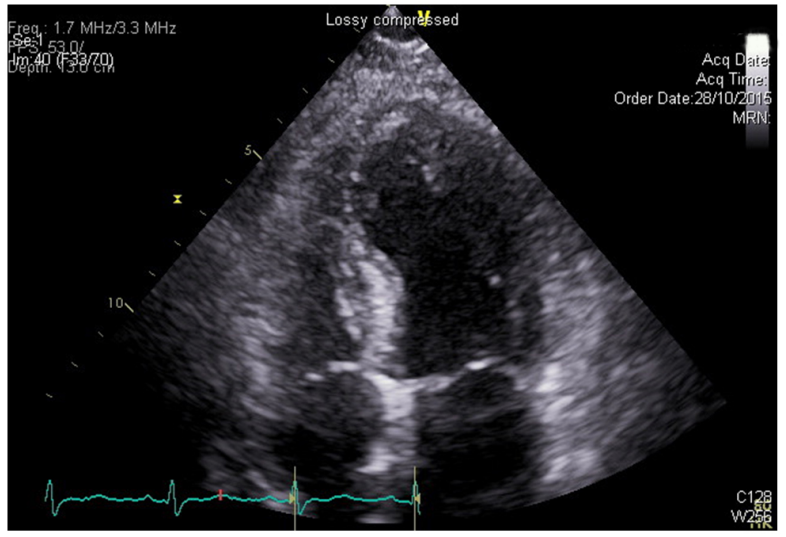

Figure 3. An echocardiogram showed mildly to moderately reduced left ventricular global systolic function and mildly reduced global systolic function of the right ventricle

The patient was then discharged with continuous Colchicine and Ibuprofen treatment.

After two months of follow-up her echocardiography study showed normalization of global systolic function. 


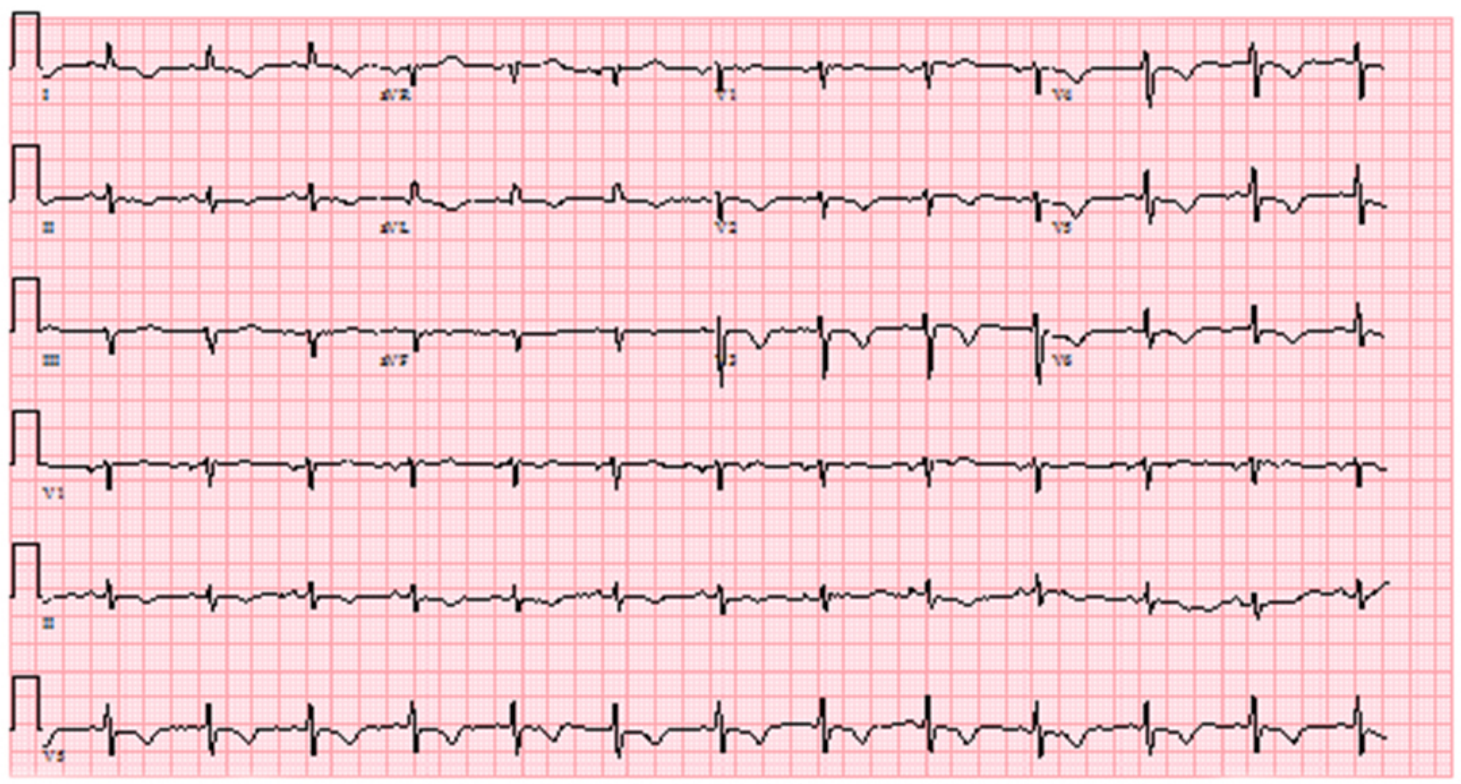

Figure 4. ECG on readmission showing deeper diffuse $\mathrm{T}$ wave inversion

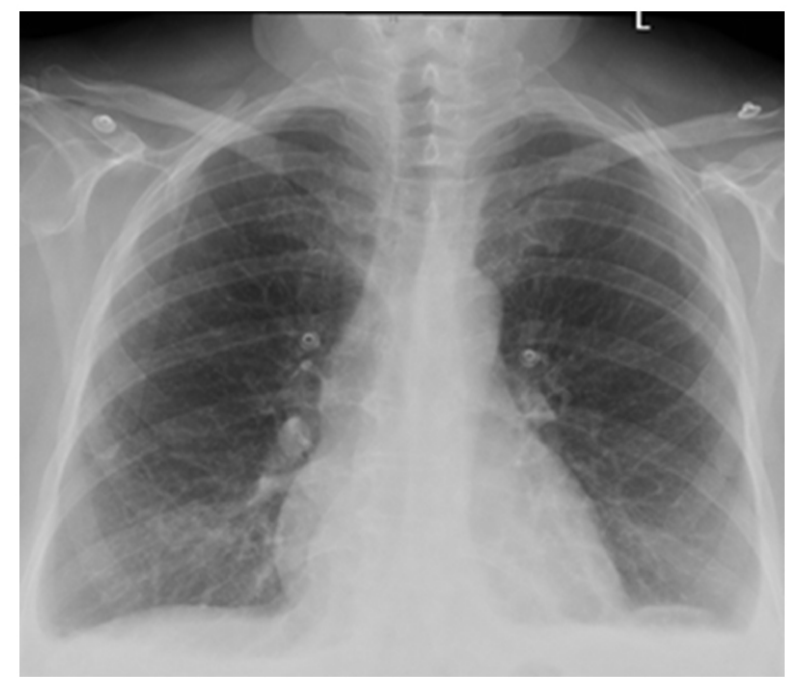

Figure 5. Chest X-Ray with bilateral pleural effusion

\section{Discussion}

Although several case reports have identified the possible TC-pericarditis association, the exact pathogenesis remains unclear. ${ }^{[20]}$ Several theories have been hypothesized to explain the TC-pericarditis connection including the transmural inflammation or myocarditis associated with TC. ${ }^{[20]}$

Another theory maintains that viral myocarditis could mimic $\mathrm{TC}$ and potentially spread to the pericardium. ${ }^{[21]}$ There are several case reports in which biopsy-proven viral myocarditis presents with left ventricular apical ballooning. ${ }^{[22]}$ This suggests that cases originally thought to be TC may have Published by Sciedu Press actually been myocarditis, mimicking TC. ${ }^{[22,23]}$ Lastly, acute pericarditis could be the primary event and TC could be its consequence. ${ }^{[21]}$ Pericarditis can cause severe pain, which could prompt catecholamine release. ${ }^{[21]}$

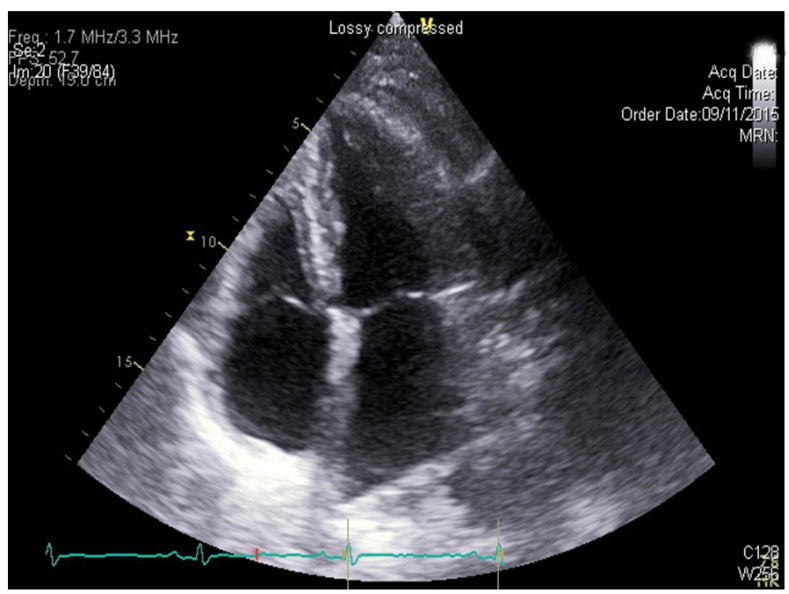

Figure 6. An echocardiography demonstrated an improved left sided global systolic function and new mild pericardial fluid effusion

Our patient's initial presentation was compatible with a diagnosis of Takotsubo cardiomyopathy. The pathogenesis of this condition is presumably based on coronary artery vasospasm leading to apical myocardial stunning accompanied often by minimal myocardial necrosis. ${ }^{[24-27]}$

Dressler's syndrome is characterized by late onset pericardi- 
tis, occurring weeks to months after the occurrence of myocardial infarction. ${ }^{[28]}$ Two weeks following the diagnosis of Takotsubo cardiomyopathy, the patient demonstrated typical features of Dressler's syndrome: pleuritic chest pain, pericardial and pleural effusion, with associated fever, leukocytosis and elevated levels of inflammatory markers. ${ }^{[28]}$ The development of Dressler's syndrome is considered to be immune-mediated with involvement of pericardium, pleura and lungs. ${ }^{[29-31]}$

In the case of our patient, Takotsubo cardiomyopathy developed into Dressler's syndrome 2 weeks later. To note, a complete immune panel was unfortunately not established. Despite this, the clinical presentation as well as the timing of disease onset strongly suggest a connection between the two entities. To date, there is scant literature available regarding Dressler's syndrome following Takotsubo cardiomyopathy, and the exact mechanism of how it develops is unclear and warrants further investigation. Though rare, clinicians should be aware of the possibility of pericarditis following apical ballooning.

\section{CONFlicts OF InTEREST Disclosure}

The authors have declared no conflicts of interest.

\section{REFERENCES}

[1] Seth PS, Aurigemma GP, Krasnow JM, et al. A syndrome of transient left ventricular apical wall motion abnormality in the absence of coronary disease: A perspective from the United States. Cardiology. 2003; 100(2): 61-6. PMid:14557691 https://doi.org/10.115 $9 / 000073040$

[2] Aurigemma GP, Tighe DA. Echocardiography and reversible left ventricular dysfunction. Am J Med. 2006; 119(1): 18-21. PMid:16431177 https://doi.org/10.1016/j.amjmed. 2005. 10.031

[3] Kawai S, Kitabatake A, Tomoike H. Guidelines for diagnosis of takotsubo (ampulla) cardiomyopathy.

[4] Wang Y, Xia L, Shen X, et al. A new insight into sudden cardiac death in young people: a systematic review of cases of Takotsubo cardiomyopathy. Medicine (Baltimore). 2015 Aug; 94 (32): e1174. PMid:26266349 https://doi.org/10.1097/MD. 00000000000 01174

[5] Scantlebury DC, Prasad A. Diagnosis of takotsubo cardiomyopathy. Circ J. 2014 Aug 25; 78(9): 2129-39. PMid:25131525 https: //doi.org/10.1253/circj.CJ-14-0859

[6] Dorfman TA, Aqel R, Mahew M, et al. Takotsubo cardiomiopathy: A reviewof the literature. Curr Cardiol Rev. 2007; 3: 137-42 https://doi.org/10.2174/157340307780618352

[7] Bybee KA, Kara T, Prasad A, et al. Systematic review: transient left ventricular apical ballooning: a syndrome that mimics ST-segment elevation myocardial infarction. Ann Intern Med. 2004 Dec 7; 141(11) 858-65. PMid:15583228 https://doi.org/10.7326/0003-481 9-141-11-200412070-00010

[8] Antonopoulos A, Kyriacou C. Apical ballooning syndrome or takotsubo cardiomyopathy: a new challenge in acute cardiac care. Cardiol J. 2008; 15: 572-7. PMid:19039766

[9] Kyriacou C. Identifying takotsubo cardiomyopathy. e-J ESC Counc Cardiol Pract. 2012; 10.

[10] Gianni M, Dentali F, Grandi AM, et al. Apical ballooning syndrome or takotsubo cardiomyopathy: A systematic review, Eur Heart J. 2006 Jul; 27(13): 1523-9. Epub. 2006 May 23. PMid:16720686 https://doi.org/10.1093/eurheartj/eh1032

[11] Terefe YG, Niraj A, Pradhan J, et al. Myocardial infarction with angiographically normal coronary arteries in the contemporary era. Coron Artery Dis. 2007 Dec; 18(8): 621-6. PMid:18004112 https : //doi.org/10.1097/MCA.0b013e3282f0efbf

[12] Pilgrim TM, Wyss TR. Takotsubo cardiomyopathy or transient left ventricular apical ballooning syndrome: A systematic review. Int
J Cardiol. 2008 Mar 14; 124(3): 283-92. PMid:17651841 https: //doi.org/10.1016/j.ijcard.2007.07.002

[13] Prasad A, Lerman A, Rihal CS. Apical ballooning syndrome (TakoTsubo or stress cardiomyopathy): A mimic of acute myocardial infarction. Am Heart J. 2008 Mar; 155(3): 408-17. PMid:18294473 https://doi.org/10.1016/j.ahj.2007.11.008

[14] Citro R, Lyon AR, Meimoun P, et al. Standard and advanced echocardiography in takotsubo (stress) cardiomyopathy: Clinical and prognostic implications. J Am Soc Echocardiogr. 2015 Jan; 28(1): 57-74. PMid:25282664 https://doi.org/10.1016/j.echo.2014.08 .020

[15] Donohue D, Movahed MR. Clinical characteristics, demographics and prognosis of transient left ventricular apical ballooning syndrome. Heart Fail Rev. 2005 Dec; 10(4): 311-6. PMid:16583180 https://doi.org/10.1007/s10741-005-8555-8

[16] La Vecchia L, Cabianca E, Vincenzi P, et al. Diagnostic criteria for apical balloning derived from quantitative analysis of left ventricular angiograms. Minerva Cardionangiol. 2010; 58: 17-21. PMid:20145592

[17] Akashi YJ, Musha H, Kida K, et al. Reversible ventricular dysfunction takotsubo cardiomyopathy. Eur J Heart Fail. 2005; 7: 1171-6. PMid:16397924 https://doi.org/10.1016/j.ejheart. 2005 .03 .011

[18] Akashi YJ, Tejima T, Sakurada H, et al. Left ventricular rupture associated with Takotsubo cardiomyopathy. Mayo Clin Proc. 2004; 79: 821-4. https://doi .org/10.1016/S0025-6196(11)62638-4

[19] Elesber AA, Prasad A, Lennon RJ, et al. Four-year recurrence rate and prognosis of the apical ballooning syndrome. J Am Coll Cardiol 2007; 50: 448-52. PMid:17662398 https://doi.org/10.1016/ j.jacc. 2007.03 .050

[20] Maruyama T, Hanaoka T, Nakajima H. Acute pericarditis in the recovery phase of transient left ventricular apical ballooning syndrome (takotsubo cardiomyopathy). Internal Medicine. 2007; 46(22): 1857-60. PMid:18025768 https://doi.org/10.2169/intern almedicine.46.0184

[21] Omar HR. Takotsubo-pericarditis association. American Journal of Emergency Medicine. 2012; 30(2): 382-3. PMid:22204996 https : //doi.org/10.1016/j.ajem.2011.10.004

[22] Bigalke B, Klingel K, May AE, et al. Human herpesvirsus 6 subtype A-associated myocarditis with "apical ballooning". Canadian Journal of Cardiology. 2007; 23(5): 393-5. https ://doi.org/10.1016/ S0828-282X (07) 70775-4

[23] Bahlmann E, Schneider C, Krause K, et al. Tako-Tsubo cardiomyopathy (apical ballooning) with parvovirus B19 genome in endomy- 
ocardial biopsy. International Journal of Cardiology. 2007; 116(1): e18-21. PMid:17098306 https ://doi .org/10.1016/j.ijcard .2006 .08 .063

[24] Ako J, Sudhir K, Farouque HM, et al. Transient left ventricular dysfunction under severe stress: brain-heart relationship revisited. Am J Med. 2006; 119: 10-7. PMid:16431176 https://doi.org/10.1 016/j.amjmed.2005.08.022

[25] Gianni M, Dentali F, Grandi AM, et al. Apical ballooning syndrome or Takotsubo cardiomyopathy: a systematic review. Eur Heart J. 2006; 27: 1523-9. PMid:16720686 https://doi.org/10.1093/ eurheartj/eh1032

[26] Kurisu S, Sato H, Kawagoe T, et al. Tako-tsubo-like left ventricular dysfunction with ST-segment elevation: A novel cardiac syndrome mimicking acute myocardial infarction. Am Heart J. 2002; 143: 448-55. PMid:11868050 https://doi .org/10.1067/mhj. 2002 .120403

[27] Dec GW. Recognition of the apical ballooning syndrome in the United States. Circulation. 2005; 111: 388-90. PMid:15687123
https://doi.org/10.1161/01.CIR.0000155234.69439.E4

[28] Dressler W. A post-myocardial infarction syndrome: preliminary report of a complication resembling idiopathic, recurrent, benign pericarditis. J Am Med Assoc. 1956; 160: 1379-83. PMid:13306560 https://doi.org/10.1001/jama.1956.02960510005002

[29] Khan AH. The postcardiac injury syndromes. Clin Cardiol. 1992; 15: 67-72. PMid:1737407 https://doi.org/10.1002/clc.496015 0203

[30] De Scheerder I, De Buyzere M, Robbrecht J, et al. Postoperative immunologic response against contractile proteins after coronary bypass surgery. Br Heart J. 1986; 56: 440-4. PMid:3491616 https://doi.org/10.1136/hrt.56.5.440

[31] Kennedy HL, Das SK. Postmyocardial infarction (Dressler's) syndrome: Report of a case with immunological and viral studies. Am Heart J. 1976; 91: 233-9. https://doi .org/10.1016/S0002-8 $703(76) 80579-0$ 